\title{
COCOA FARMERS' SAFETY PERCEPTION AND COMPLIANCE WITH PRECAUTIONS IN THE USE OF PESTICIDES IN CENTRE AND WESTERN CAMEROON
}

\author{
OYEKALE, A. S. \\ Department of Agricultural Economics and Extension, \\ North-West University Mafikeng Campus, Mmabatho 2735, South Africa \\ (e-mail: asoyekale@gmail.com; phone:+27787144271) \\ (Received $12^{\text {th }}$ Sep 2016; accepted $15^{\text {th }}$ Dec 2016)
}

\begin{abstract}
Although pesticides are necessary inputs in cocoa production, inability of farmers to comply with safety precautions poses significant threat to their health and sustainable cocoa production in Cameroon. This paper analyzed the determinants of compliance with pesticide safety guideliness among cocoa farmers. Data were collected with structured questionnaires administered to 667 cocoa farmers and analyzed with descriptive statistics and Negative Binomial regression. The results showed that majority of the farmers were males, with more than 10 years of farming experience. Awareness of safety precautions in handling pesticides was high. Among the safety kits, boots were owned by $62.26 \%$ and $76.87 \%$ of the farmers from Ngoumou and Buea, respectively. Safety compliance in the use of insecticides increased significantly $(\mathrm{p}<0.05)$ with land areas, being married and compliance with manufacturers' instructions but reduced with farmers' age, practice of touching it with bare hand and residence in Nogoumou (region). However, compliance with safety while handling fungicides significantly increased with being married but reduced with practice of touching it with bare hands. It was concluded that addressing the health risks associated with inappropriate handling of pesticides by cocoa farmers is paramount, and educating them on the need to follow manufacturers' instruction is necessary.
\end{abstract}

Keywords: agrochemicals, safety precautions, safety kits, compliance, Negative Binomial Regression

\section{Introduction}

Cocoa ranks among the most important cash crops in Cameroon (Nfinn, 2005). Historically grown since 1886 (Ardener, 1996), cocoa agro-forestry has gained significant prominence in the country's agricultural landscape with about $37 \%$ of total croplands now devoted to its cultivation (Anonymous A, 2016). Considered on the ranking trail, Cameroon was the fifth highest cocoa producer in the world in 2013/2014 (Ngalame, 2014). Similarly, the contributions of cocoa to Cameroonian economy ever since the country obtained independence in 1960 cannot be overemphasized. Employment generated from cocoa value chain is quite enormous with the number of households deriving their primary incomes from its cultivation estimated at close to 600,000 (Mahob et al., 2014). Cameroon's cocoa outputs increased from 211,000 metric tons in $2013 / 2014$ to 232,000 metric tons in 2014/2015, although some projections indicated that cocoa production would decrease to 230,000 metric tons in 2015/2016 (Statistical Portal, 2016).

It should be emphasized that smallholder farmers that dominate cocoa sub-sector in Cameroon are largely besieged by poverty. This goes contrary to the tenet of sustainability, which was defined in Article 39 of the International Cocoa Agreement of 2001 as the intersection of social, economic and environmental benefits in cocoa production (United Nations Conference on Trade and Development, 2010). The fundamental role of policy in ensuring significant transmission of economic returns from cocoa production to smallholder cocoa farmers - who are the primary producers - 
is somewhat mismatched. This is presumptuously pathetic given several production risks and marketing uncertainties that an average cocoa farmer annually faces in their quest towards making some cogent ends meet. Many cocoa farmers are therefore subjected to periodic financial risks and economic instability, among other obliviously compounded socioeconomic consequences.

Emergence of climate change as a global environmental problem conspicuously undermines cocoa productivity with persistent droughts coupled with outbreak of pests and diseases. Specifically, one of the major production risks in cocoa agriculture is the growing problem of pests and diseases (Edith, 2016). In Cameroon, among the most common and highly destructive cocoa pests are mirids (Bisseleua et al., 2011; Babin et al., 2010), which could be responsible for between 30 to $70 \%$ of cocoa yield losses (Anikwe et al., 2009). Another pest of significance in cocoa cultivation is pod borer, which could account for about 50\% of cocoa yield losses in Cameroon (Fule, 2013) and 42 to $49 \%$ in Malaysia (Day, 1989).

In addition, in Cameroon, black pod disease, caused by fungus of Phytophthora sp. (Mahob et al., 2014) is a notorious form of attack on cocoa pods, which often accounts for significant yield losses depending on the effectiveness of adopted management practices and timeliness of spraying cocoa pods with appropriate agrochemicals (Guest, 2007). Specifically, potential cocoa yield losses as a result of black pod disease could be between 20-30\% (Ndoumbe-Nkeng et al., 2004; Drenth and Guest, 2004). Another estimate indicated that potential global cocoa production losses as a result of black pod and pod rot fungal diseases could be as high as 44\% (Mahob et al., 2014).

Therefore, the need to control cocoa's pests and diseases cannot be overemphasized. This often necessitates application of insecticides and fungicides. In Cameroon, where government's support to cocoa farmers is at best minimal, smallholder farmers are left to decide on the type and quantity of agrochemicals they apply on their farms. In the 1980s, Cameroonian government set up Société de Développement du Cacao (SODECAO) as an institution to oversee sustainable cocoa production. Part of the assigned roles was provision of timely and reliable technical assistances to farmers on proper usage of agrochemicals. The Office National de Cacao et Café (ONCC) later took over those responsibilities (Alary, 1996; Janin, 1996) until the liberalization policies were implemented in the 1990s. As applied to the cocoa sector, the policies mandated removal of the subventions that farmers were getting along with other critical technical assistances in procurement, distribution and application of agrochemicals (Alary, 1996; Coulibaly et al., 2002; Sonwa et al., 2008).

Given this neglect, cocoa farmers were unable to get required trainings on proper use of agrochemicals, which subjects many farmers to significant health risks in the course of handling those chemicals. The World Health Organization (2005) noted that in some instances, farmers that handle fungicides to address black pod disease and capsid insects may lack the requisite information and knowledge for handling its inherent toxicity (WHO, 2005). Therefore, excessive exposure to pesticides may result during mixing, application and post-application treatments of sprayers (Gockowski and David, 2007). Okolle et al. (2014) noted that although policies for regulating utilization of pesticides are available in Cameroon, institutional mechanisms for ensuring adequate monitoring of the likelihood of deliberate or non-deliberate misuses are deficient. Similarly, poor farmers may not be able to acquire agrochemical safety kits, while ignorance may undermine its usage among those that were able to procure them (Okolle et al., 2014). 
Several health challenges have been reported as a result of mishandling of pesticides among farmers in developing countries. Hicks (2012) noted that about 2.2 million farmers are at risk to different health problems as a result of frequent exposure to some pesticides. The associated health risk from agrochemical exposure could be enormous due to existence of several channels through which their active compounds could get inside human bodies. These include direct injection through contacts with food or accidental injection through the mouth, inhalation and dermal penetration as a result of contacts with human skins. The risk of being affected is high among those that handle and spray the chemicals. There have also been cases of health complaints among farmers as a result of eating agricultural products that have been contaminated by pesticides (Hicks, 2012). Some of the health risks associated with exposure to pesticides could be in the form of headache, stomach pains, immune system suppression, respiratory problems, vomiting, skin irritation, permanent damages to the eyes and dizziness, among others (Amuoh, 2011; Hicks, 2012; Monosson, 2012).

Its significant relevance to agricultural and health policy debates notwithstanding, there is dearth of studies on compliance with pesticide safety guides in academic literature. More importantly, very little had been documented for Cameroon. In some related literature, Okoffo et al. (2016) analyzed compliance of Ghanaian cocoa farmers to agrochemical safety guides. The results showed that farmers' age, farming experience, agricultural extension access, presence of retail agrochemical shops, land areas cultivated and education significantly influenced decision to use protective kits when handling agrochemicals.

A study by Ajayi and Akinnifesi (2005) found that farmers were properly aware of the need to protect themselves from having direct contacts with agrochemicals. Such protective instructions include wearing of glasses in order to avoid contacts with eyes, wearing of boot to ensure stability while spraying chemicals, wearing of hand gloves in order to avoid contacts with hands, wearing of order to protect the nose and mouth. However, Raksanam et al. (2012) and Isin and Yildirim (2007) found that despite the fact that farmers realized the need to properly read manufacturers' instructions on pesticides, about $40 \%$ did not deem it fit to follow them to letters. This goes in line with the findings of Issa et al. (2015) who noted that despite that some Nigerian farmers were aware of safety measure in the use of agrochemicals, compliance was very low. In another study, Mekonnen and Agonafir (2002) found that farmers had some negative impressions on the need to wear some recommended protective kits while spraying agrochemicals. This paper seeks to analyze determinants of cocoa farmers' compliance with the use of safety kits during cocoa spraying.

\section{Materials and methods}

\section{The study areas}

The study was carried out in Ngoumou in the Centre region of Cameroon and Buea in the western region. Ngoumou is a town located in Cameroon's central region. It is the head of the Department of Méfou-et-Akono. At the 2005 census, the municipality had 13,923 inhabitants, of which 5240 were residing in Ngoumou town. It is located on latitude $3^{\circ} 42^{\prime} 00^{\prime \prime} \mathrm{N}$ and longitude $11^{\circ} 26^{\prime} 00^{\prime \prime} \mathrm{E}$ (National Geospatial-Intelligence Agency, 2016).

Buea is a town with historic significance located in western part of Cameroon. It has humid climate with distinct dry and rainy seasons spanning from November to February and March to 
October, respectively. The region receives more rainfall than any other place in the country. Agriculture remains one of the most prominent industries in the area, and cocoa is largely grown by the farmers (University of Buea, 2016). The town's geographical coordinates are latitude $4^{\circ} 09^{\prime} 09^{\prime \prime} \mathrm{N}$ and longitude $9^{\circ} 14^{\prime} 27^{\prime \prime} \mathrm{E}$ with elevation of about $870 \mathrm{~m}$ above sea levels. The town has a population of 131, 325 in the 2005 population census, with males and females being approximately ratio one to one (National Institute of Statistics, Cameroon, 2016). It is located about $60 \mathrm{~km}$ from Douala, which is Cameroon's economic capital and about $15 \mathrm{~km}$ from Atlantic Ocean (Nsagha et al., 2012). People of different ethnic groups are in Buea although the Bakweri are the indigenous occupants of the land.

\section{Sampling methods}

Multi-stage sampling method was used for data collection. The first stage involved random selection of villages, after which households were sampled based on population proportional to size. The total number of respondents from Buea was 402 while 265 cocoa farming households were sampled from Ngoumou. Table 1 shows the distribution of the number of respondents across each of the selected villages.

Table 1. Distribution of the cocoa farmers across the selected villages in Cameroon

\begin{tabular}{|c|c|c|c|c|c|}
\hline Villages & Freq. & Percent & Villages & Freq. & Percent \\
\hline \multicolumn{3}{|c|}{ Ngoumou (Yaounde) } & \multicolumn{3}{|l|}{ Buea } \\
\hline AkokBekoe & 21 & 7.92 & Three Corner & 4 & 1.00 \\
\hline Bikop & 5 & 1.89 & Big Ekombe & 9 & 2.24 \\
\hline Boa-Bakundu & 1 & 0.38 & Boa-Bakundu & 4 & 1.00 \\
\hline Ekoumdoum & 10 & 3.77 & Ekiliwindi & 26 & 6.47 \\
\hline Fegmimban 3 & 36 & 13.58 & EkombeEbongi & 7 & 1.74 \\
\hline Kamba & 24 & 9.06 & Ekona & 17 & 4.23 \\
\hline Muea & 5 & 1.89 & Ekumbe & 12 & 2.99 \\
\hline MvouNkeng & 20 & 7.55 & Etam & 9 & 2.24 \\
\hline Nkoakom & 10 & 3.77 & Ikiliwindi & 18 & 4.48 \\
\hline NkolAkono 1 & 26 & 9.81 & Kake & 13 & 3.23 \\
\hline NkolEbem Essie & 8 & 3.02 & Kang & 17 & 4.23 \\
\hline Nkol Messi I & 14 & 5.28 & Kombone Mission & 10 & 2.49 \\
\hline NkolNgaMbida & 2 & 0.75 & Konye & 7 & 1.74 \\
\hline Nkolendom & 15 & 5.66 & Kumba & 23 & 5.72 \\
\hline Nkolngambida & 2 & 0.75 & Likomba & 10 & 2.49 \\
\hline Nkon-Biwia & 5 & 1.89 & Mabanda & 36 & 8.96 \\
\hline NkongZok & 25 & 9.43 & Malende & 7 & 1.74 \\
\hline Nkong-Bimvia & 2 & 0.75 & Mbonge & 4 & 1.00 \\
\hline Nkong-Nen I & 14 & 5.28 & Muea & 19 & 4.73 \\
\hline NkwaKom & 8 & 3.02 & Mukonge & 16 & 3.98 \\
\hline Nvom-Nkeng & 3 & 1.13 & Muyuka & 11 & 2.74 \\
\hline \multirow[t]{8}{*}{ Ofoumou I } & 9 & 3.40 & Nkamlikum & 6 & 1.49 \\
\hline & & & Ntam & 15 & 3.73 \\
\hline & & & Shumbo & 4 & 1.00 \\
\hline & & & Teke & 25 & 6.22 \\
\hline & & & Water Fall & 36 & 8.96 \\
\hline & & & Waterfall Tombel & 24 & 5.97 \\
\hline & & & Wome & 4 & 1.00 \\
\hline & & & Yoke & 9 & 2.24 \\
\hline Total & 265 & 100.00 & Total & 402 & 100.00 \\
\hline
\end{tabular}




\section{Estimated models}

The dependent variable that was used to capture compliance in the estimated model was the number of protective kits that farmers were wearing in the course of spraying pesticides (insecticides and fungicides). Specifically, the questionnaire probed into whether farmers were wearing hand gloves, safety boots, overall dress, google and ventilation masks. A count of the number of kits that were normally wore by farmers represents the dependent variable. The count nature of the dependent variable warranted the use of Poisson regression. Following Jacob (2002), the model is specified in Eq. 1:

$$
\operatorname{Pr}[Y=y]=\frac{e^{\lambda} \lambda^{y}}{y !}, y=0,1,2 . .
$$

where average number of occurrence within a certain interval of time is denoted by $\lambda$. The log linear model specification is presented in Eq. 2 as:

$$
\ln \lambda_{i}=x_{i}^{\prime} \beta
$$

Given equation Eq. 2, the mean of occurrences within a certain period of time can be specified as in Eq 3 and 4:

$$
\begin{gathered}
E\left[y_{i} \mid x_{i}\right]=\lambda_{i}=e^{x_{i} \beta} \\
\frac{\partial E\left[y_{i} \mid x_{i}\right]}{\partial x_{i}}=\lambda_{i} \beta_{i}
\end{gathered}
$$

Therefore,

The model is estimated using maximum likelihood estimation method. The likelihood equation is specified as Eq. 5,

$$
\ln L=\sum_{i=1}^{n}\left[-\lambda_{i}+y_{i} x_{i}^{\prime} \beta-\ln y_{i} !\right]=\sum_{i=1}^{n}\left[-e^{\mathbf{x}_{i}^{\prime} \beta}+y_{i} x_{i}^{\prime} \beta-\ln y_{i} !\right]
$$

The estimated parameters are expressed as in Eq 6:

$$
\frac{\partial L}{\partial \beta}=-\sum_{i=1}^{n}\left[\mathbf{x}_{i}\left[e^{\mathbf{x}_{i}^{\prime} \beta}-y_{i}\right]\right]=0
$$

The independent variables that were included are land areas (acres), age of farmers, marital status (married $=1,0$ otherwise), gender (male $=1,0$ otherwise), formal education in secondary or tertiary levels (yes $=1,0$ otherwise), farming as primary occupation (yes $=1,0$ otherwise), household size, follow manufacturers' instructions (yes $=1,0$ otherwise), inhale it (yes $=1,0$ otherwise), tastes it (yes $=1,0$ otherwise), 
drink it (yes $=1,0$ otherwise), touch it with bare hand (yes $=1,0$ otherwise), enter the eyes (yes $=1,0$ otherwise), touch the skins (yes $=1,0$ otherwise), region Ngoumou $=1$, 0 otherwise).

After estimating the Poisson regression, the goodness of fit was tested to determine whether the model is best for the data. Invoking "gof estat" command in STATA software brings the goodness of fit statistics. In this analyses, they both show statistical significance $(\mathrm{p}<0.01)$. These imply that the model does not fit well and another model should be tested. The Negative Binomial regression was therefore used in this study.

\section{Results and discussions}

\section{Socioeconomic profiles of cocoa farmers}

Table 2 shows the socio-economic characteristics of cocoa farmers across the selected regions in Cameroon. It reveals that majority of the farmers from Ngoumou and Buea were males, with $91.3 \%$ and $91.0 \%$, respectively. Similar results had been reported by Levai et al. (2015). These results are expected given that cocoa farming is highly tedious (Anonymous B, 2016; Oluyole et al., 2013). In some instances, women are only able to own cocoa farms if inherited, after demise of their husbands or with the assistance of males in carrying out some tedious operations if the land is newly acquired.

Table 2. Socioeconomic characteristics of cocoa farmers in Cameroon

\begin{tabular}{|l|l|l|l|l|l|l|}
\hline Socioeconomic groups & \multicolumn{2}{l}{ Ngoumou } & \multicolumn{2}{l|}{ Buea } & \multicolumn{2}{l|}{ All Farmers } \\
\hline & Freq & $\%$ & Freq & $\%$ & Freq & \% \\
\hline Gender & & & & & & \\
\hline Male & 242 & 91.3 & 366 & 91.0 & 608 & 91.2 \\
\hline Female & 23 & 8.7 & 36 & 9.0 & 59 & 8.8 \\
\hline Marital Status & & & & & & \\
\hline Single & 46 & 17.4 & 100 & 24.9 & 146 & 21.9 \\
\hline Married & 187 & 70.6 & 281 & 69.9 & 468 & 70.2 \\
\hline Divorced & 9 & 3.4 & 7 & 1.7 & 16 & 2.4 \\
\hline Widow & 23 & 8.7 & 14 & 3.5 & 37 & 5.5 \\
\hline Educational Levels & & & & & & \\
\hline Primary & 110 & 41.5 & 178 & 44.3 & 288 & 43.2 \\
\hline Secondary & 139 & 52.5 & 184 & 45.8 & 323 & 48.4 \\
\hline Tertiary & 10 & 3.8 & 23 & 5.7 & 33 & 4.9 \\
\hline Adult Education & 3 & 1.1 & 3 & 0.7 & 6 & 0.9 \\
\hline Primary Occupation & & & & & & \\
\hline None & 3 & 1.1 & 14 & 3.4 & 17 & 2.5 \\
\hline Farming & 234 & 88.3 & 343 & 85.3 & 577 & 86.5 \\
\hline Artisan & 4 & 1.5 & 9 & 2.2 & 13 & 1.9 \\
\hline Trading & 4 & 1.5 & 20 & 5.0 & 24 & 3.6 \\
\hline Civil Service & 9 & 3.4 & 8 & 2.0 & 17 & 2.5 \\
\hline Transport & 2 & 0.8 & 4 & 1.0 & 6 & 0.9 \\
\hline Others & 4.5 & 18 & 4.5 & 30 & 4.5 \\
\hline Age of Farmers & & & & & & \\
\hline$<30$ & & 5.66 & 53 & 13.18 & 68 & 10.19 \\
\hline
\end{tabular}




\begin{tabular}{|l|l|l|l|l|l|l|}
$30<40$ & 45 & 16.98 & 99 & 24.63 & 144 & 21.59 \\
\hline $40<50$ & 72 & 27.17 & 118 & 29.35 & 190 & 28.49 \\
\hline $50<60$ & 81 & 30.57 & 71 & 17.66 & 152 & 22.79 \\
\hline $60<70$ & 39 & 14.72 & 37 & 9.20 & 76 & 11.39 \\
\hline$=>70$ & 13 & 4.91 & 24 & 5.97 & 37 & 5.55 \\
\hline Household Size & & & & & & \\
\hline $1-2$ & 28 & 10.57 & 35 & 8.71 & 63 & 9.45 \\
\hline $3-4$ & 37 & 13.96 & 87 & 21.64 & 124 & 18.59 \\
\hline $5-6$ & 70 & 26.42 & 104 & 25.87 & 174 & 26.09 \\
\hline $7-8$ & 50 & 18.87 & 81 & 20.15 & 131 & 19.64 \\
\hline$>8$ & 80 & 30.19 & 95 & 23.63 & 175 & 26.24 \\
\hline Farming Experience & & & & & & \\
\hline$<10$ & 32 & 12.08 & 146 & 36.32 & 178 & 26.69 \\
\hline $10<20$ & 49 & 18.49 & 104 & 25.87 & 153 & 22.94 \\
\hline $20<30$ & 64 & 24.15 & 80 & 19.90 & 144 & 21.59 \\
\hline $30<40$ & 40 & 15.09 & 53 & 13.18 & 93 & 13.94 \\
\hline $40<50$ & 49 & 18.49 & 13 & 3.23 & 62 & 9.30 \\
\hline $50<60$ & 24 & 9.06 & 4 & 1.00 & 28 & 4.20 \\
\hline$>=60$ & 7 & 2.64 & 2 & 0.50 & 9 & 1.35 \\
\hline
\end{tabular}

Furthermore, about $70 \%$ of the cocoa farmers in each of the regions were married. The result is in support of that of Okoffo et al. (2016) for Ghana and Levai et al. (2015) for Cameroon. Being married ensures availability of farm support through supply of unpaid family labour (International Programme on the Elimination of Child Labour, 2005). This may be fundamental to cocoa farming success given that less than one out of three cocoa farmers in the selected regions was less than 40 years old, and more than $40 \%$ had family size of more than seven members. Substantial findings from previous studies have highlighted ageing of cocoa farmers (Nzouankeu and Felix, 2014) and non-willingness of youths to take over cocoa farming due to its low level of profitability (Fule, 2014). However, majority of the farmers had experience in farming for more than 10 years. This finding is in accordance with that of Okoffo et al. (2016) for some farmers in Ghana. Under normal circumstances, experience should enhance profitability which is critical for poverty reduction among cocoa farmers, most especially given their very low scale of operation.

Furthermore, majority of the farmers attained formal education at the primary or secondary levels. The farmers' low competitiveness in labour trading is linked to their low level of education. Some previous studies have highlighted low level of education among cocoa farmers (Aneani et al., 2012; Fule, 2014, 2013). This also partly explains their being primarily engaged in farming, which was reported by majority of the farmers.

\section{Insecticides and fungicides usage, precautions taken and safety kits ownership}

Table 3 presents the forms of insecticides and fungicides being used by the farmers and the trend of their uses in the past five years. It reveals that in Ngoumou and Buea, $42.64 \%$ and $95.77 \%$ of the farmers were using liquid insecticides, respectively while $29.43 \%$ and $77.11 \%$ used liquid fungicides. However, solid fungicides were used by $67.17 \%$ and $77.11 \%$ of the cocoa farmers from Ngoumou and Buea, respectively. The results emphasize the essentiality of agrochemicals in cocoa production. Specifically, 
the use of fungicides cannot be compromised, given high prevalence of highly virulent form of cocoa black pod disease known as Phytophthoramegakarya (Gockowski and Mva, 2001). Incidence of pests infestation on cocoa farms often compels the use of insecticides, but this is not so common among cocoa farmers in Cameroon. Sonwa et al (2008) submitted that fungicides such as Kocide, Nordox, Ridomil and Cacaobre constitute the most used pesticide in Southern Cameroon and they are copper based.

Table 3. Form of pesticides used by cocoa farmers and trends in Cameroon

\begin{tabular}{|c|c|c|c|c|c|c|c|c|c|c|c|c|}
\hline \multirow[b]{3}{*}{ Form of chemicals } & \multicolumn{4}{|c|}{ Ngoumou } & \multicolumn{4}{|c|}{ Buea } & \multicolumn{4}{|c|}{ All Farmers } \\
\hline & \multicolumn{2}{|c|}{ Insecticide } & \multicolumn{2}{|c|}{ Fungicides } & \multicolumn{2}{|c|}{ Insecticide } & \multicolumn{2}{|c|}{ Fungicides } & \multicolumn{2}{|c|}{ Insecticide } & \multicolumn{2}{|c|}{ Fungicides } \\
\hline & Freq & $\%$ & Freq & $\%$ & Freq & $\%$ & Freq & $\%$ & Freq & $\%$ & Freq & $\%$ \\
\hline Liquid & 113 & 42.64 & 78 & 29.43 & 385 & 95.77 & 39 & 9.70 & 498 & 74.66 & 117 & 17.54 \\
\hline Solid & 35 & 13.21 & 178 & 67.17 & 10 & 2.49 & 310 & 77.11 & 45 & 6.75 & 488 & 73.16 \\
\hline \multicolumn{13}{|l|}{ Trend of use } \\
\hline Increasing & 47 & 17.74 & 90 & 33.96 & 298 & 74.13 & 270 & 67.16 & 345 & 51.72 & 360 & 53.97 \\
\hline Decreasing & 35 & 13.21 & 57 & 21.51 & 6 & 1.49 & 10 & 2.49 & 41 & 6.15 & 67 & 10.04 \\
\hline The Same & 71 & 26.79 & 97 & 36.60 & 81 & 20.15 & 63 & 15.67 & 152 & 22.79 & 160 & 23.99 \\
\hline
\end{tabular}

The results in Table 3 further show that $17.74 \%$ and $74.13 \%$ of the farmers in Ngoumou and Buea indicated increase in the trends of insecticide usage in the past five years respectively. However, fungicide usage was indicated to have increased by $33.96 \%$ and $67.16 \%$ of the farmers from Ngoumou and Buea respectively. These results emphasize the persistence of pests and diseases as fundamental problem in Cameroon's cocoa agro-forestry. Edson, Ntsefong, and Zachée (2013) noted this concern for increasing agricultural productivity in Cameroon.

Table 4 shows awareness of cocoa farmers on precautions to be taken while using pesticides. It reveals that for the combined dataset, $77.66 \%$ and $87.41 \%$ were respectively aware of safety measures to be taken while handling or using insecticides and fungicides, respectively. Farmers from Buea had higher awareness for insecticides (95.20\%). Specifically, not keeping within the reach of children (91.70\%), not inhaling (90.94\%) had highest awareness among farmers in Ngoumou as against no contacts with food and drinks (87.81\%), and not keeping within the reach of children $(81.59 \%)$ for farmers from Buea. The need to have a pit where left overs of pesticides should be poured was less aware of in Ngoumou and Buea with $46.04 \%$ and $63.18 \%$, respectively. The results general show high level of awareness on issues related to the need for farmers to avoid human contacts with pesticides due to its toxicity. However, it does not reflect consciousness of farmers on adverse ecological impacts of pesticides since absence of a pit where chemical leftovers are poured implies indiscriminate disposal. This is contrary to the tenets of good practices in relation to pesticide usage (Pimentel et al., 1980).

The results in Table 5 show that $35.85 \%$ and $62.26 \%$ of the farmers from Ngoumou possessed hand gloves and safety boots respectively, as against $50.25 \%$ and $76.87 \%$ for Buea. However, overall clothing and goggle for protecting chemicals from entering eyes during spraying were used by $29.43 \%$ and $27.55 \%$ of the farmers from Ngoumou respectively compared to 31.84 and $28.11 \%$ for those from Buea. Ventilation masks were possessed by $30.19 \%$ and $31.09 \%$ of the farmers from Ngoumou and Buea, respectively. 
Table 4. Safety measures' awareness and precautions taken by cocoa farmers in handling pesticides in Cameroon

\begin{tabular}{|l|l|l|l|l|l|l|}
\hline & \multicolumn{2}{l|}{ Ngoumou } & \multicolumn{2}{l|}{ Buea } & \multicolumn{2}{l|}{ Farmers } \\
\hline Precautions & Freq & $\%$ & Freq & $\%$ & Freq & $\%$ \\
\hline Awareness (Insecticides) & 136 & 51.32 & 382 & 95.02 & 518 & 77.66 \\
\hline Awareness (Fungicides) & 232 & 87.55 & 351 & 87.31 & 583 & 87.41 \\
\hline Do not handle with bare hand & 169 & 63.77 & 305 & 75.87 & 474 & 71.06 \\
\hline Do not keep within the reach of children & 243 & 91.70 & 328 & 81.59 & 571 & 85.61 \\
\hline Do not inhale the chemical & 241 & 90.94 & 323 & 80.35 & 564 & 84.56 \\
\hline Do not pour the left over inside river or stream & 214 & 80.75 & 298 & 74.13 & 512 & 76.76 \\
\hline $\begin{array}{l}\text { Have a pit dug within the farm where left over of chemicals are } \\
\text { poured }\end{array}$ & 122 & 46.04 & 254 & 63.18 & 376 & 56.37 \\
\hline Ensure no contact of chemicals with food or drink & 227 & 85.66 & 353 & 87.81 & 580 & 86.96 \\
\hline Ensure it is kept under specified temperature & 163 & 61.51 & 325 & 80.85 & 488 & 73.16 \\
\hline
\end{tabular}

Table 5. Safety kits owned by cocoa farmers during handling of pesticides in Cameroon

\begin{tabular}{|l|l|l|l|l|l|l|l|}
\hline & \multicolumn{2}{l|}{ Ngoumou } & \multicolumn{2}{l|}{ Buea } & \multicolumn{2}{l|}{ All Farmers } \\
\hline Safety Kits & Freq & $\%$ & Freq & $\%$ & Freq & $\%$ \\
\hline Hand gloves & 95 & 35.85 & 202 & 50.25 & 297 & 44.53 \\
\hline Safety boots & 165 & 62.26 & 309 & 76.87 & 474 & 71.06 \\
\hline Overall & 78 & 29.43 & 128 & 31.84 & 206 & 30.88 \\
\hline Goggle & 73 & 27.55 & 113 & 28.11 & 186 & 27.89 \\
\hline Ventilation mask & 80 & 30.19 & 125 & 31.09 & 205 & 30.73 \\
\hline
\end{tabular}

Hand gloves and overall are meant to protect farmers' hands and body from direct contacts with pesticides. This becomes necessary to avoid skin burns as a result of contact with toxic pesticides. Safety boot is to protect the legs of the farmers from contacts with pesticides and to maintain stability while spraying. Eyes are protected by the google and nose is to be protected from inhaling toxic odours from chemicals by the ventilation mask. Low possession of the safety kits is in line with some previous studies such as Okoffo et al. (2016), Antwi-Agyakwa (2013), Ogunjimi and Farinde (2012), Sosan and Akingbohungbe (2009) and Sosan et al. (2008).

\section{Determinants of cocoa farmers' safety compliance}

In order to model the determinants of cocoa farmers' compliance with safety precautions during cocoa spraying, models for the number of safety kits that were wore were estimated. The models seek to determine the factors explaining the number of safety kits that farmers normally wear while spraying insecticides and fungicides. The model as presented in Eq. 2 was estimated with Poisson regression given the count nature of the dependent variable.

The included explanatory variables were tested for multicollinearity using the level of tolerance, which was computed as the reciprocal of variance inflation factor (VIF). The results showed that multicollinearity was not a problem as reflected by high tolerance of the included variables. However, econometric procedures require that estimated Poisson models should be tested in order to determine if Poisson regression 
model is adequate or not. Given that STATA 12 software was used, post estimation command to determine the goodness of fit of the estimated Poisson models showed statistical significance $(p<0.01)$. Therefore, Poisson regression model was considered inappropriate and Negative Binomial regression was considered.

The results for the Negative Binomial regression in Table 6 for the two models were considered adequate given the statistical significance of the likelihood ratio tests of alpha is equal to zero $(\mathrm{p}<0.01)$. More specifically, based on the estimated likelihood ratio chi square statistics, the models were statistically significant $(\mathrm{p}<0.01)$. This implies that the estimated parameters were not jointly equal to zero. In the model for insecticides, included variables showed statistical significance $(\mathrm{p}<0.05)$ for land areas, age of farmers, being married, following manufacturers' instructions, touch it with bare hands, and region. However, in the fungicide model, only being married and touch it with bare hands showed statistical significance.

Table 6. Negative Binomial Regression Results of the determinants of number of safety kits wore during cocoa spray

\begin{tabular}{|c|c|c|c|c|c|c|}
\hline \multirow[t]{2}{*}{ Variables } & \multicolumn{3}{|l|}{ Insecticides } & \multicolumn{3}{|l|}{ Fungicides } \\
\hline & Coefficients & Std. Error & Tolerance & Coefficients & Std. Error & Tolerance \\
\hline Land areas & $0.0360 * * *$ & 0.0098 & 0.9451 & 0.0039 & 0.0112 & 0.9427 \\
\hline Age of farmers & $-0.0078 * *$ & 0.0030 & 0.8707 & -0.0042 & 0.0030 & 0.8681 \\
\hline Married & $0.3157 * * *$ & 0.0848 & 0.9227 & $0.2630 * * *$ & 0.0840 & 0.9205 \\
\hline Male & -0.1159 & 0.1268 & 0.9617 & 0.0308 & 0.1290 & 0.9652 \\
\hline $\begin{array}{l}\text { Formal } \\
\text { education } \\
\text { (secondary or } \\
\text { tertiary) }\end{array}$ & 0.0707 & 0.0665 & 0.9419 & -0.0088 & 0.0680 & 0.9377 \\
\hline $\begin{array}{ll}\text { Farming as } \\
\text { primary } \\
\text { occupation }\end{array}$ & $-0.1890^{*}$ & 0.1028 & 0.9450 & -0.0482 & 0.1068 & 0.9460 \\
\hline Household size & 0.0063 & .0109 & 0.9021 & 0.0012 & 0.0104 & 0.8936 \\
\hline $\begin{array}{l}\text { Follow } \\
\text { manufacturers' } \\
\text { instructions }\end{array}$ & $1.3694 * * *$ & 0.1291 & 0.6545 & 0.1322 & 0.0979 & 0.7064 \\
\hline Inhale it & -0.1381 & 0.1008 & 0.4576 & 0.0150 & 0.1035 & 0.5168 \\
\hline Tastes it & 0.2286 & 0.2742 & 0.6982 & 0.0571 & 0.2109 & 0.8528 \\
\hline Drink it & 0.0026 & 0.3316 & 0.6837 & -0.0887 & 0.2805 & 0.8484 \\
\hline $\begin{array}{l}\text { Touch it with } \\
\text { bare hand }\end{array}$ & $-0.4529 * * *$ & 0.1142 & 0.6382 & $-0.5596 * * *$ & 0.1060 & 0.5980 \\
\hline Enter the eyes & -0.1537 & 0.0952 & 0.5038 & -0.1240 & 0.0989 & 0.5468 \\
\hline $\begin{array}{l}\text { Touch the } \\
\text { skins }\end{array}$ & 0.0011 & 0.0804 & 0.6579 & -0.0384 & 0.0888 & 0.6146 \\
\hline Region & $-0.5718 * * *$ & 0.1074 & 0.4854 & -0.0088 & 0.1045 & 0.5151 \\
\hline Constant & -.0159929 & .2453612 & & .7732541 & .2355304 & \\
\hline lnalpha & -1.64125 & .2691959 & & -1.223863 & .1838498 & \\
\hline Alpha & .1937378 & .0521534 & & .2940918 & .0540687 & \\
\hline Number of obs & 665 & & & 664 & & \\
\hline LR chi2(15) & 290.43 & & & 74.80 & & \\
\hline Prob> chi 2 & 0.0000 & & & 0.0000 & & \\
\hline Log likelihood & -1041.2252 & & & -1188.1272 & & \\
\hline $\begin{array}{l}\text { Likelihood- } \\
\text { ratio test of } \\
\text { alpha=0 }\end{array}$ & chibar2(01) & $21.39 * * *$ & & chibar2(01) & $53.91 * * *$ & \\
\hline
\end{tabular}


The results show that holding other variables as constant, as farmers' land areas increased by one acre, the log of number of safety kits that are wore during cocoa spraying would increase by 0.036 . The result is similar to that of Okoffo et al. (2016). The implication is that farmers with large farm sizes seemed to take caution in wearing the necessary safety kits while spraying cocoa farms. This may reflect farmers' perception of higher likelihood of being exposed to cocoa chemicals if the farm size to be sprayed is large. It may also reiterate the fact that small scale cocoa farmers may consider purchase of safety kits from their incomes unnecessary their low profit margins.

As farmers' age increased by one year, the log of number of safety kit wore during cocoa spraying decreased by 0.0078 . Okoffo et al. (2016) found similar result and explained that ageing farmers are likely to be stereotyped given their persistent familiarization with their old ways of doing things. Therefore, aged farmers may not be so conscious about the negative health impacts of having contacts with insecticides. It may also imply that as they grow older, sufficient experience on how to handle insecticides efficiently even if safety kits were not wore had been acquired.

Furthermore, the log of number of safety kits that married farmers wear during insecticide spraying is significantly higher by 0.3157 when compared with that for unmarried farmers. This variable also has significant parameter in the fungicide model. However, the farmers who indicated to be following manufacturers' instructions have their log of number of safety kits wore significantly higher by 1.3694 when compared with those who did not. This is expected because those instructions often highlight the need for proper protection during handling of insecticides. The farmers who indicated to be touching insecticides with bare hands had their log of number of safety kits wore reduced by 0.4529 , when compared with those who indicated not to be touching it with bare hands. This result is expected because exposure of hands to insecticides is an indication of not wearing hand gloves or overall. The parameter of region indicates that farmers from Ngoumou had their log of number of safety kits wore during insecticide spraying reduced by 0.5718 , when compared with those from Buea.

\section{Conclusion}

Cocoa agriculture requires significant input of pesticides. Inability of farmers to comply with safety precautions poses significant health hazards to them, and this would also affect long run productivity of cocoa. This study found that although many of the farmers were aware of safety precautions in handling pesticides, compliance was very low. Similarly, ownership of safety kits was generally low among the farmers. The study identified the need for cocoa farmers to follow manufacturers' instructions on the pesticides in order to enhance compliance with safety precautions. Similarly, the smallness of the farming operations reduced compliance of farming with the safety precautions. This calls for significant insights on proper orientation and education given that health hazards of pesticides may not be directly related to the volume. The farmers from Ngoumou were not using much of protective safety kits. This calls for proper interventions among the farmers. It also emphasizes the need for definite interventions to understand the practices of farmers from Ngoumou on handling of agrochemicals. The results similarly pointed at the need for targeted interventions to educate aged farmers on the necessity of complying with some safety precautions in the handling of pesticides. 


\section{REFERENCES}

[1] Ajayi, O.C., Akinnifesi, F.K. (2005): Farmers' understanding of pesticide safety labels and field spraying practices: a case study of cotton farmers in northern Côte d'Ivoire. Scientific Research and Essay 2 (6): 204-210.

[2] Alary, V. (1996): Libéralisation de la filièrecacaoyère: vueetvécue par les planteurs du Cameroun. - Rev. Rég. Dévelop 4:1-24.

[3] Amuoh, C.N. (2011): A case study of health risk estimate for pesticide-users of fruits and vegetable farmers in Cameroon. Master's dissertation submitted in partial fulfillment of the requirements for the degree of Master of Nutrition and Rural Development, Faculty of Bioscience Engineering, Universiteit Gent. Available online: http://lib.ugent.be/fulltxt/RUG01/001/789/883/RUG01-001789883_2012_0001_AC.pdf (Accessed on 20 June 2016).

[4] Aneani, F., Anchirinah, V.M., Owusu-Ansah, F., Asamoah, M. (2012): Adoption of some cocoa production technologies by cocoa farmers in Ghana'. - Sustainable Agriculture Research 1(1):103-117.

[5] Anikwe, J.C., Omoloye, A.A., Aikpokpodion, P.O., Okelana, F.A., Eskes, A.B. (2009): Evaluation of resistance in selected cocoa genotypes to the brown cocoa mirid, Sahlbergellasingularis. - Crop Protection 28 (4): 350-355.

[6] Anonymous A: The sustainability of Cameron cocoa economy. Available online: http://www.icco.org/sites/www.roundtablecocoa.org/documents/3\%20Mr.\%20Ngo\%20N kelle\%20Victor\%20-\%20Cameroon.pdf (Accessed on 12 ${ }^{\text {th }}$ June 2016).

[7] Anonymous B: The working in Ghana project. Available online: http://web.cgu.edu/faculty/wickera/cocoa.htm (Accessed: 30 August 2016).

[8] Antwi-Agyakwa, A.K. (2013): Susceptibility of field populations of cocoa mirids, sahlbergellasingularishaglund and distantiellatheobroma (distant) to bifenthrin.(Unpublished Master's thesis). - Kwame Nkrumah University of Science and Technology, Kumasi, Ghana.

[9] Ardener, E. (1996). Kingdom on Mount Cameroon: studies in the history of the Cameroon Coast, 1500-1700. - Berghahn Books, Oxford.

[10] Babin R., Hoopen, G.M., Cilas, C., Enjalric, F., Yede, Gendre, P., Lumaret, J.P. (2010): Impact of shade on the spatial distribution of Sahlbergellasingularis Hag. (Hemiptera: Miridae) in traditional cocoa agroforests. - Agricultural and Forest Entomology 12:69-79.

[11] Bisseleua, H.B.D., Yede, Vidal, S. (2011): Dispersion models and sampling of cacao mirid bug sahlbergellasingularis (Hemiptera: Miridae) on Theobroma cacao in southern Cameroon. - Entomological Society of America 40 (1):111-119.

[12] Coulibaly, O., Mbila, D., Sonwa, D.J., Adesina, A., Bakala, J. (2002): Responding to economic crisis in sub-Saharan Africa: New farmer-developed pest management strategies in cocoa-based plantations in Cameroun. - Integrated Pest Management Review 7:165-172.

[13] Day, R.K. (1989): Effect of cocoa pod borer, Conopomorphacramerella, on cocoa yield and quality in Sabah, Malaysia. - Crop Protection 8 (5) 332-339.

[14] Drenth, A., Guest, D.I. .(2004): Phytophthora in the tropics. - In: Drenth, A., Guest, D.I. (eds.) Diversity and Management of Phytophthora in Southeast Asia. p. 238. ACIAR Monograph No. 114. ACIAR, Canberra, Australia.

[15] Edith, L.K.: Main risks in cocoa sector of Cameroon. Available online: https://www.ermacademy.org/publication/risk-management-article/main-risks-cocoa-sector-cameroon (Accessed on 12 June 2016).

[16] Edson, M.Y.J., Ntsefong, G.N., Zachée, A. (2013): Development of integrated pest management system in agricultural production in Cameroon and the central African sub region. - World Journal of Agricultural Research 1(6):133-142. 
[17] Fule, C.B. (2013): Historic cocoa farming in Cameroon: Future for Smallholders?. Available online: http://www.siani.se/news/blog/chi_benieh_fule (Accessed on 31 August 2016).

[18] Fule, C.B. (2014): Small-scale versus large-scale cocoa farming in Cameroon which farm type is more ready for the future? Available online: http://stud.epsilon.slu.se/6438/1/Fule_CB_140218.pdf (Accessed: 30 August 2016).

[19] Gockowski, J., David, S. (2007): Farm Safety Interventions in the Cocoa Sector. Available online: http://www.iita.org/c/document_library/get_file?p_l_id=98898\&folderId=99883\&name= DLFE-1116.pdf (Accessed on 20 June 2016).

[20] Gockowski, J., Mva, J. (2001): Labour practices in the cocoa sector of cameroon with a special focus on the role of children. - International Institute of Tropical Agriculture (IITA) Report.Yaounde, Cameroon: IITA.

[21] Guest, D. (2007): Black pod: diverse pathogens with a global impact on cocoa yield. Phytopathology 97:1650-1653.

[22] Hicks, B. (2012): Agricultural pesticides and human health. Available online: http://serc.carleton.edu/NAGTWorkshops/health/case_studies/pesticides.html (Accessed on 20 June 2016).

[23] International Programme on the Elimination of Child Labour (IPECL) (2005): Combating child labour in cocoa growing. Available online: http://www.ilo.org/public//english/standards/ipec/themes/cocoa/download/2005_02_cl_co coa.pdf (Accessed on 30 August 2016).

[24] Isin, S., Yildirim, I. (2007): Fruit-growers' perceptions on the harmful effects of pesticides and their reflection practices: The case of Kemalpasa, Turkey. - Crop Protection 26: 917-922.

[25] Issa, F. O., Atala, T. K., Akpoko, J. G., Sanni, S. A. (2015): Adoption of Recommended Agrochemical Practices among Crop Farmers in Kaduna and Ondo States, Nigeria. Journal of Agricultural Extension 19 (1).

[26] Jacob, J.A. (2002): Poisson regression. Available online: http://faculty.smu.edu/tfomby/eco6375/data/poisson\%20regression.ppt. (Accessed on 31 August 2016.

[27] Janin, P. (1996): Un planteur sans Etatpeut-il encore être un planteur? - Polit. Afric. 62: 45-56.

[28] Levai, L.D., Meriki, H.D., Adiobo, A., Awa-Mengi, S., Akoachere J.-F.T.K., Titanji, V.P.K. (2015): Postharvest practices and farmers'perception of cocoa bean quality in Cameroon. - Agriculture and Food Security 4:28.

[29] Mahob, R.J., Ndoumbè-Nkeng, M., Ten Hoopen, G.M., Dibog, L., Nyassé, S., Rutherford, M., Mbenoun, M., Babin, R., Mbang, J.A.A., Yede, Bilong Bilong, C.F. (2014): Pesticides use in cocoa sector in Cameroon: characterization of supply source, nature of actives ingredients, fashion and reasons for their utilization. - International Journal of Biological and Chemical Sciences 8 (5): 1976-1989.

[30] Mekonnen, Y., Agonafir, T. (2002): Pesticide sprayers' knowledge, attitude and practice of pesticide use on agricultural farms of Ethiopia. - Occupational Medicine 52(6): 311315 .

[31] Monosson, E. (2012): The Encyclopedia of Earth. Agricultural pesticide contamination. 11 Feb. 2011. National Council for Science and the Environment. 04. Nov. 2012.

[32] National Geospatial Intelligence Agency, Ngoumou: Cameroon, Available online: http://www.geographic.org/geographic_names/name.php?uni=$4452552 \&$ fid $=1354 \& \mathrm{c}=$ cameroon (Accessed on 20 June 2016.

[33] National Institute of Statistics (2016): Cameroon. Population and housing census. Internet Available online: http://cameroon.opendataforafrica.org/fizfxjc/population-and-housingcensus (Accessed on 26 August 2016). 
[34] Ndoumbe-Nkeng, M., Cilas, C., Nyemb, E., Nyasse, S., Bieysse, D., Flori, A., Sache, I. (2004): Impact of removing diseased pods on cocoa black pod caused by Phytophthoramegakarya and on cocoa production in Cameroon. - Crop Protection 23:415-424.

[35] Nfinn, T. (2005): Cocoa Production in Cameroon. AFTA 2005 Conference Proceedings. Available online: http://www.worldagroforestry.org/treesandmarkets/inaforesta/documents/agrof_cons_bio div/cocoa\%20cameroon.pdf (Accessed on 20th June 2016).

[36] Ngalame, E.N. (2014): Soggy weather takes a bit out of cocoa income in Cameroon TRFN. Available online: http://www.reuters.com/article/cameroon-cocoaidUSL6N0TL42020141202 (Accessed on 12 June 2016).

[37] Nsagha, D., Njunda, A., Kamga, H., Assob, J., Bongkem, E. (2012): HIV-1/HIV-2 coinfection among voluntary counseling testing subjects at a regional hospital in Cameroon. - African Journal of Health Sciences 12 (3): 276-281.

[38] Nzouankeu, A.M., Felix, B. (2014): Ageing farmers, low-yield crops hurt Cameroon's cocoa ambitions. Available online: http://www.reuters.com/article/us-cameroon-cocoaoutput-analysis-idUSKBNOEK13P20140609 (Accessed on 30 August 2016).

[39] Ogunjimi, S.I., Farinde, A.J. (2012): Farmers' knowledge level of precautionary measures in agro-chemicals usage on cocoa production in Osun and Edo States, Nigeria. International Journal of Agriculture and Forestry 2(4):186-194.

[40] Okoffo, E.D., Mensah, M., Fosu-Mensah, B.Y. (2016): Pesticides exposure and the use of personal protective equipment by cocoa farmers in Ghana. - Environmental Systems Research 5:17.

[41] Okolle, J.N., Tataijiang, P., Ngome, F.A. (2014): Evaluation of farmer's knowledge on pests and diseases of vegetables and their management practices in three different agroecological zones in Cameroon. Available online: https://humidtropics.cgiar.org/wpcontent/report2013docs/Cameroon\%20Crop\%20protect $\% 20$ study\%20Report.pdf (Accessed on 20 June 2016).

[42] Oluyole, K.A., Dada, O.A., Oni, O.A., Adebiyi, S., Oduwole, O.O. (2013): Farm labour structure and its determinants among cocoa farmers in Nigeria. - American Journal of Rural Development 1(1): 1-5.

[43] Pimentel, D. Andow, D, Dyson-Hudson, R.O., Gallahan, D., Jacobson, S., Irish, M., Kroop, S., Moss, A., Vinzant, B. (1980): Environmental and social cost of pesticide: A preliminary assessment. - Agriculture, Ecosystems and Environment 34: 127-140.

[44] Raksanam B., Taneepanichskul S., Siriwong W., Robson M.G. (2012): Multi-approach model for improving agrochemical safety among rice farmers in Pathumthani, Thailand. Risk Management and Healthcare Policy 5: 75-82.

[45] Sonwa, D.J., Coulibaly, O., Weise, S.F., Adesina , A.A., Janssens, M.J.J. (2008): Management of cocoa: constraints during acquisition and application of pesticides in the humid forest zones of southern Cameroon. - Crop Protection 27: 1159-1164.

[46] Sosan, M.B., Akingbohungbe, A.E. (2009): Occupational insecticide exposure and perception of safety measures among cacao farmers in Southwestern Nigeria. - Archieves of Environmental and Occupational Health 64(3): 185-193.

[47] Sosan, M.B., Akingbohungbe, A.E., Ojo, I.A.O., Durosinmi, M.A. (2008): Insecticide residues in the blood serum and domestic water source of cacao farmers in Southwestern Nigeria. - Chemosphere 72(5): 781-784.

[48] Statistical Portal (2016): Global cocoa bean production from 2012/2013 to 2015/2016, by country (in 1,000 metric tons). Available online: http://www.statista.com/statistics/263855/cocoa-bean-production-worldwide-by-region/ (Acccessed on 20 June 2016) 
[49] Tchokote, J, Dontsop Nguezet, P.M., Onyebuchi, O.K. (2015): An economic appraisal of cocoa production in Cameroon: the case study of Lekie division. - Journal of Economic and Sustainable Development 6 (9):168-181.

[50] United Nations (2011): International cocoa agreement 2010. August 2011. Available online: http://www.icco.org/about-us/international-cocoa-agreements/cat_view/2-iccoagreements-and-their-history/3-2010-international-cocoa-agreement.html. (Accessed on 20 June 2016).

[51] United Nations Conference on Trade and Development (2010): International Cocoa Agreement. Available online: http://unctad.org/en/Docs/tdcocoa10d5_en.pdf (Accessed on 18 June 2016).

[52] University of Buea: The town of Buea. Available online: http://www.ubuea.cm/about/thetown-of-buea/ (Accessed on 26 August 2016).

[53] World Health Organization (2005): The WHO recommended classification of pesticides by hazard and guidelines to classification: 2004. WHO, Geneva. 